\title{
DINAMIKA KASUS AHMADIYAH DAN ALIRAN KEPERCAYAAN LAINNYA SERTA PENYELESAIANNYA MELALUI HUKUM TERTULIS DI INDONESIA
}

\author{
Siti Hamimah \\ Fakultas Hukum Universitas Singaperbangsa Karawang \\ Jl. HS.Ronggo Waluyo, Puseurjaya, Telukjambe Timur, Kabupaten Karawang, \\ Jawa Barat 41361 \\ Email : siti.hamimah96@yahoo.co.id
}

\begin{abstract}
Abstrak: Pemerintah secara resmi mengakui enam agama (Islam, Kristen, Katolik, Hindu, Budha, Konghucu). Secara umum Pemerintah menghargai kebebasan menjalankan ibadah agama, namun demikian pembatasan yang terus berlangsung dari pemerintah, khususnya pada agama yang tidak diakui dan agama yang dianggap menyimpang dari agama yang diakui merupakan pengecualian dari pelaksanaan penghormatan kebebasan beragama. Meskipun pemerintah pusat mengontrol hal-hal yang berkaitan dengan agama, pemerintah pusat tidak berusaha untuk membatalkan peraturan daerah yang membatasi hak seperti yang dijamin oleh Undang-undang Dasar. Pengikut kelompok agama minoritas terus mengalami beberapa diskriminasi resmi dalam bentuk kesulitan di bidang administrasi, seringkali dalam konteks pencatatan sipil untuk akta pernikahan dan kelahiran atau berkenaan dengan pengeluaran kartu penduduk. Berdasarkan hal tersebut, rumusan masalah yang diangkat dalam penelitian ini yaitu pertama: Bagaimana dinamika kasus Ahmadiyah dan pengaturan tentang identitas keagamaan pada kartu tanda penduduk ? Kedua: Bagaimana penyelesaiannya terhadap agama dan aliran kepercayaan lainnya yang belum di akui melalui hukum tertulis di Indonesia ? Adapun tujuan daripada penelitian ini yaitu pertama untuk mengetahui dinamika kasus ahmadiyah dan pengaturan tentang identitas keagamaan pada kartu tanda penduduk, kedua, untuk menganalisis penyelesaiannya terhadap agama dan aliran kepercayaan lainnya yang belum di akui melalui hukum tertulis di Indonesia. Jenis penelitian ini adalah penelitian normatif empiris. Hasil yang diperoleh dari penelitian ini adalah bahwa: pertama, penganut dari kepercayaan yang belum di akui resmi oleh pemerintah boleh mengosongkan kolom agama dalam KTP elektronik atau e-KTP. Pemerintah Kabupaten/Kota berkewajiban dan bertanggung jawab menyelenggarakan urusan Administrasi kependudukan yang dilakukan oleh Bupati/ Walikota dengan kewenangan. Kedua, Dinamika kasus Ahmadiyah dan penyelesaiannya terhadap agama pemerintah sebagai lembaga tertinggi sebuah Negara harus bersikap netral.
\end{abstract}

Kata Kunci: Undang-undang Dasar, Kebebasan Beribadah dan Pemerintah

Abstract: Thegovernment officially recognizes six religions (Islam, Christian, Catholic, Hinduism, Buddhism, Confucian). In general, the government respects the freedom of worship. 
However, certain recognition has also created limitation, especially towards unrecognized beliefs and that deemed deviate from the six recognized religions, which has been the reason to exempt its believers from principle of freedom of worship. In spite of the fact that the government has control upon religious matters, it does not show its effort to revoke local regulations which limit the right guaranteed by the constitution. Followers of minority religious groups continue to experience some discrimination in administrative matters, specifically in the context of civil registration for marriage and birth certificates or with regard to the issuance of resident identification card. Thus, the problem formulations used in this research would be on the dynamic of Ahmadiyah case and control of religious identification in ID; and on the solution of problems regarding to unrecognized religions under the law. The aim of this research is to, first, understand the dynamic of Abmadiyah case and control of religious identification in ID and, second, to analyse the solution for unrecognized religions. This type of research is empirical normative research. This research has presented a result that, first, believers of unrecognized beliefs may empty the column of their religion in the electronic ID (e-KTP), and that district and city government is obliged and responsible to administer civil administrative matter conducted by Regent/Mayor with authority. Second, the dynamic of Ahmadiyah case; where government neutrality as the highest state authority is at stake.

Keywords:Constitution, Freedom of Worship, Government

\section{Pendahuluan}

Pada hakikatnya, manusia sebagai makhluk sosial memiliki kemauan untuk hidup bersama dengan manusia-manusia lain, terutama dengan manusia-manusia yang sama alat-alat hidupnya, sehingga dapat memunculkan kolektivitas dengan kemauan-kemauan yang kolektif tersebut maka mudah sekali mengadakan kelompok-kelompok ataupun suku-suku. ${ }^{1}$ Atas dasar persamaan, apakah dalam bentuk persamaan asal,bahasa, sejarah, cita-cita maka suku bangsa ataupun beberapa suku bangsa pada akhirnya akan mengalami resultante (kesadaran) yakni dalam kesadaran merasa diri sebagai satu bangsa. ${ }^{2}$

$$
\text { Indonesia merupakan suatu }
$$

Negara yang memiliki keberagaman baik dari suku, bahasa maupun agama. Keberagaman ini telah disadari oleh para pendiri Negara kita sehingga melahirkan suatu semboyan yaitu Bhineka Tunggal Ika yang dapat diartikan sebagai berbeda-beda akan

\footnotetext{
1 erwin muhammad, pendidikan kewarganegaraan republik indonesia, reflika aditama, bandung, 2013, hlm. 51
} 
tetapi tetap satu. ${ }^{3}$ Secara positif masalah agama pada perorangan dan keberagaman merupakan suatu masyarakat. ${ }^{4}$

kekuatan yang apabila dapat digunakan dengan baik merupakan suatu potensi bagi kemajuan Negara akan tetapi bila keberagaman tersebut mengakibatkan suatu perpecahan dan kebencian maka keberagamanini menjadi suatu kekuatan negatif yang dapat menghancurkan bangsa Indonesia.

Jika kita mengacu pada dasar negara sila pertama Pancasila dan pasal 29 konsitusi yaitu UUD1945, Indonesia dapat dipandang sebagai negara yang "monotheist" karena pernyataan bahwa Negara berdasarkan atas Ketuhanan Yang Maha Esa dapat ditafsirkan demikian. Atas dasar inilah, Indonesia tidak dapat dikategorikan sebagai Negara agama karena dalam konstitusi tidak dinyatakan bahwa negara didasarkan atas suatu agama tertentu, tetapi Indonesia juga bukan merupakan Negara sekuler yang memperhatikan permasalahan agama dan menyerahkan

\footnotetext{
${ }^{3}$ Hayatun Na'imah, "Perda Berbasis Syari'ah Dalam Tinjauan Hukum Tata Negara," Khazanah: Jurnal Studi Islam dan Humaniora 14, no. 1 (2016): 27-40.
}

mengabulkan permohonan uji materi terkait aturan pengosongan kolom agama pada Kartu Keluarga (KK) dan Kartu Tanda Penduduk (KTP). Hal itu diatur dalam pasal 61 Ayat (1) dan (2), serta pasal 64 ayat (1) dan (5) UU No 23 Tahun 2006 tentang Administrasi Kependudukan juncto UU No 24 Tahun 2013 tentang UU Adminduk. ${ }^{5}$ Berbagai konflik dan kekerasan yang berlatar belakang agama menunjukkan bahwa Indonesia masih belum dapat menjalankan dan memberikan perlindungan terhadap hak asasi manusia khususnya tentang kebebasan beragama dalam hal ini terkait dengan hak warga Negara untuk secara bebas menjalankan kepercayaan yang diyakininya. Perlindungan terhadap kebebasan beragama pada dasarnya telah dinyatakan dan diatur secara jelas

4 sigit ardianto, 2009, from secularism into modifed pluralism : comprehensive application of john rawls's justice as fairness theory in defining state and religion r'1elationship, cornell law library

5 https://tirto.id/kasus-kasus-intoleransiyang-menimpa-ahmadiyah-cp4v, diakses tanggal 19 desember 2017 
dalam pasal 28 dan 29 UUD1945 serta dipertegas melalui Undang-undang Nomor 39 Tahun1999 tentang Hak Asasi Manusia dan melalui peratifikasian berbagai konvensi internasional antaralain ICCPR.

\section{Berbagai pembatasan dan} pelanggaran termasuk penyegelan, pembakaran, penyerangan atas nama agama adalah pelanggaran hak asasi manusia seperti yang terdapat dalam Pasal 18 ayat (3) International Covenant On Civil And Political Rights. Khususnya terhadap penghayat kepercayaan dari penganut suatu agama. Selama ini, para penghayat kepercayaan seperti Sunda Wiwitan, Batak Parmalim, Ugamo Bangsa Batak dan Sapto Darmo mengalami diskriminasi dalam mengakses layanan publik. Pasalnya, kolom agama dalam KK dan KTP mereka dikosongkan. Hal itu berdampak pada sulitnya mengurus hak-hak sipil politik, seperti melamar pekerjaan, menikah dan mengakses layanan publik lainnya.

\footnotetext{
Adanya putusan MK, penganut aliran kepercayaan memliki kedudukan hukum sama dengan pemeluk enam agama yang telah di akui
}

oleh Pemerintah dalam memperoleh hak terkait administrasi kependudukan. Mahkamah Konstitusi memecahkan kebuntuan itu. MK dituntut menafsirkan pasal untuk memperadabkan bangsa. Apabila proses tersebut benar, idealitas yang dibangun dalam penegakan hukum di Indonesia sejajar dengan upaya bangsa mencapai tujuan Nasional. Idealitas itu akan menjauhkan dari praktek ketimpangan hukum yang tak terkendali seperti sekarang ini.

Sehingga, Indonesia dimasa depan tidak ada lagi dskriminasi hokum. Penegakan hukum tidak hanya kecerdasan intelektual, melainkan dengan kecerdasan spiritual. Artinya, dengan kata lain penegakan hukum yang dilakukan dengan penuh determinasi, empati, dedikasi, komitmen terhadap penderitaan bangsa dan disertai keberanian untuk mencari jalan lain daripada yang biasa dilakukan. ${ }^{6}$

${ }^{6}$ satjipto rahardjo, penegakan bukum suatu tinjauan sosiologis, genta publishing, yogyakarta, 2009, hlm. xiii 
Berdasarkan uraian di atas, penulis tertarik untuk mengangkat penelitian ini dengan judul: "Dinamika Kasus Ahmadiyah Dan Aliran Kepercayaan Lainnya Serta Penyelesaiannya Melalui Hukum Tertulis Di Indonesia"

\section{Rumusan Masalah}

Adapun yang menjadi fokus penelitian ini adalah:

1. Bagaimana Dinamika Kasus Ahmadiyah dan Pengaturan tentang Identitas keagamaan pada Kartu Tanda penduduk?

2. Bagaimana penyelesaiannya terhadap agama dan aliran kepercayaan lainnya yang belum di akui melalui hukum tertulis di Indonesia?

\section{Tujuan Penelitian}

Tujuan penelitian ini adalah untuk merumuskan beberapa fokus masalah, yaitu:

1. Mengetahui dinamika kasus ahmadiyah dan pengaturan tentang identitas keagamaan pada kartu tanda penduduk
2. Menganalisis penyelesaiannya terhadap agama dan aliran kepercayaan lainnya yang belum di akui melalui hukum tertulis di Indonesia.

\section{Metode Penelitian}

Metode penelitian yang digunakan adalah gabungan dari metode pendekatan yang bersifat normatif dan metode bersifat empiris. Dengan menggabungkan kedua metode ini yaitu melihatkenyataan dilapangan dengan menerangkan ketentuan-ketentuan dalam peraturan perundang-undangan yang berlaku, kemudian dianalisis dengan membandingkan antara tuntutan nilainilai ideal yang ada dalam peraturan perundang- undangan dengan kenyataan yang ada dilapangan.

\section{Hasil Dan Pembahasan}

Dinamika Kasus Ahmadiyah dan Pengaturan Tentang Identitas Keagamaan pada Kartu Tanda Penduduk

Tindakan intoleransi yang dialami Jemaat Ahmadiyah Indonesia 
bukan kali ini saja. Sebagai kelompok minoritas, Ahmadiyah seringkali menjadi target tindakan pelanggaran kebebasan beragama dan berkeyakinan. Hal ini dapat dilihat dari laporan tahunan Komnas HAM maupun Setara Institute. ${ }^{7}$ Berdasarkan catatan Setara Institute, sejak 2012 sampai 2015, JAI menjadi korban pelanggaran hak-hak konstitusional dalam isu keagamaan atau keyakinan dalam 164 peristiwa. Jumlah ini menunjukkan betapa intens komunitas muslim Ahmadiyah menjadi sasaran intoleransi dan persekusi. Laporan tahunan Komnas HAM menunjukkan, dari Januari-Desember 2016, ada 22 dari 97 pengaduan pelanggaran hak atas kebebasan beragama dan berkeyakinan terhadap JAI.

Jumlah itu naik dari 17 pengaduan pada 2015. Data ini menunjukkan persekusi terhadap muslim Ahmadiyah masih jadi masalah serius di bawah pemerintahan Joko Widodo. Sejumlah riset baik oleh

\footnotetext{
7https://news.detik.com/berita/3695848/ komnas-ham-ahmadiyah-korbandiskriminasi-karena-uu-pnps, diakses tanggal 19 desember 2017
}

Komnas HAM, Setara Institute, dan Wahid Institute, yang mereka rilis setiap tahun, kerap menyebutkan bahwa pemerintah daerah, baik provinsi maupun kabupaten/kota, adalah pelaku terbanyak yang melakukan pelanggaran terhadap hak atas kebebasan beragama dan berkeyakinan. Sejak era Susilo Bambang Yudhoyono, pelanggaran terhadap kebebasan beragama meningkat, tidak hanya pada Ahmadiyah, tetapi pada kelompok minoritas Syiah, Baha'i, Kristen, dan Gafatar.

Intoleransi menjadi pembicaraan publik selama beberapa tahun. Dalam kasus terbaru bahkan populer sebutan "persekusi" sesudah vonis terhadap Basuki "Ahok" Thajaja Purnama karena dakwaan penodaan agama. Pemerintahan Jokowi, termasuk pada 1 Juni kemarin, menegaskan ide "Pancasila" sebagai basis negara, dan dirayakan secara resmi sebagai upaya negara menetralisir kekerasan berbasis sentimen agama. Komisi Nasional Hak Asasi Manusia (Komnas HAM) menilai Ahmadiyah menjadi korban diskriminasi. Hal ini terjadi karena 
pemberlakuan Undang-Undang

Pencegahan Penyalahgunaan dan/atau Penodaan Agama.

Komunitas Ahmadiyah korban diskriminasi dalam beragam wujudnya. Itu terjadi antara lain karena pemberlakuan UU Nomor 1 PNPS Tahun 1965. Maka jelas maksud pembuat UU sebagai pencegahan penyelahgunaan penodaan agama. Tetapi norma di dalamnya seiring berjalannya waktu kabur, sehingga multitafsir yang menyimpang. Dulu preventif sekarang menjadi represif. Itu konsekuensi kandungan diskriminasi. Ada kata yang tidak jelas dalam UU PNPS itu. kata 'di muka umum' dalam pasal 1 UU PNPS memberi peluang intervensi. Kandungan kata yang tidak jelas yakni 'di muka umum' memberikan peluang besar aparat dan masyarakat melakukan intervensi forum interum. Sebagai kata turunan yang tidak jelas, pemerintah memiliki wewenang melarang agama menyimpang.

Putusan MK bernomor Nomor 97/PUU-XIV/2016 yang mengakomodir aliran kepercayaan dalam KTP, menuai kekhawatiran masuknya gerakan atau paham-paham lain yang dilarang tapi ingin diakui dalam KTP. Pasalnya, para penganut kepercayaan itu berhasil mengoreksi ketentuan di UU Administrasi Kependudukan soal mengosongkan kolom agama di KTP bagi penganut kepercayaan. Argumentasinya adalah asas keadilan, karena selama ini mereka diperlakukan beda dengan mereka yang mencantumkan agama di KTP. Keadilan adalah inti atau hakikat hukum. Keadilan tidak hanya dapat dirumuskan secara matematis bahwa yang dinamakan adil bila seseorang mendapatkan bagian yang sama dengan orang lain. Demikian pula, keadilan tidak cukup dimaknai dengan simbol angka sebagaimana tertulis dalam sanksi-sanksi KUHP, misalnya angka 15 tahun, 5 tahun, 7 tahun dan seterusnya. Karena keadilan sesungguhnya terdapat dibalik sesuatu yang tampak dalam angka tersebut (metafisis), terumus secara filosofis oleh petugas hukum/hakim.

Berdasarkan sudut hak asasi manusia dan pemenuhan hak sipil warga negara, keputusan MK itu 
sangat penting dan akan memberikan dampak luas terhadap langkah-langkah untuk memberikan jaminan dan kepastian hukum bagi penghayat kepercayaan di Indonesia, yang perlu dilakukan pemerintah, pertama, melakukan pendataan mengenai penganut/penghayat kepercayaan. Tidak perlu ada pembatasan penghayat yang diakui atau tidak diakui. Kedua, memastikan hak-hak penganut aliran kepercayaan dipenuhi pemerintah.

Sebagaimana diketahui, ada 187 aliran kepercayaan tingkat pusat di Indonesia yang tercatat di Kementerian Pendidikan dan Kebudayaan. Penyelesaian Putusan MK itu membuat Kementerian Dalam Negeri perlu mengubah UU Adminduk, mengakomodir 187 aliran kepercayaan di sistem kependudukan, dan mengubah format e-KTP menjadi agama/kepercayaan.

Penyelesaian Terhadap Agama dan Aliran Kepercayaan lainnya yang Belum di Akui Melalui Hukum Tertulis di Indonesia
Sejumlah warga penghayat kepercayaan bersukacita setelah Mahkamah Konstitusi mengabulkan permohonan uji materi terkait aturan pengosongan kolom agama pada Kartu Keluarga (KK) dan Kartu Tanda Penduduk (KTP). Mereka mengajukan uji materi Pasal 61 Ayat (1) dan (2), serta pasal 64 ayat (1) dan (5) UndangUndang Nomor Nomor 23 Tahun 2006 tentang Administrasi Kependudukan juncto UndangUndang Nomor 24 Tahun 2013 tentang Perubahan Atas UndangUndang Nomor 23 Tahun 2006 tentang Administrasi Kependudukan (UU Adminduk).

Dalam putusannya, Majelis Hakim MK berpendapat bahwa kata "agama" dalam Pasal 61 ayat (1) dan Pasal 64 ayat (1) bertentangan dengan UUD 1945 dan tidak mempunyai kekuatan hukum mengikat secara bersyarat sepanjang tidak termasuk penganut aliran kepercayaan.Artinya, penganut aliran kepercayaan memiliki kedudukan hukum yang sama dengan pemeluk enam agama yang diakui pemerintah, dalam memperoleh hak terkait administrasi kependudukan. MK 
memutuskan pasal 61 Ayat (2) dan Pasal 28E ayat (1) dan ayat (2) UUD pasal 64 ayat (5) UU Adminduk 1945, agama dan kepercayaan sangat bertentangan dengan UUD 1945 dan mungkin dipahami sebagai dua hal tidak mempunyai kekuatan hukum yang berbeda atau tidak sama. Namun mengikat.Pasal 61 ayat 2 berbunyi: keduanya sama-sama diakui

"Keterangan mengenai kolom agama sebagaimana dimaksud pada ayat (1) bagi Penduduk yang agamanya belum diakui sebagai agama sesuai dengan ketentuan Peraturan Perundang-undangan atau bagi penghayat kepercayaan tidak diisi, tetapi tetap dilayani dan dicatat dalam database kependudukan."Pasal 64 ayat 5 menyatakan, "Elemen data penduduk. tentang agama sebagaimana dimaksud pada ayat (1) bagi penduduk yang agamanya belum diakui sebagai agama berdasarkan ketentuan Peraturan Perundang-undangan atau bagi penghayat kepercayaan tidak diisi, tetapi tetap dilayani dan dicatat dalam database kependudukan."

Hakim MK Maria Farida Indrati mengatakan, secara tekstual, Pasal 28E ayat (1) dan ayat (2) serta Pasal 29 ayat (2) UUD 1945 menempatkan agama selalu berkaitan dengan kepercayaan, di mana agama adalah kepercayaan itu sendiri. Dengan membaca dan memahami keberadaan eksistensinya.Pemahaman tersebut muncul karena Pasal 28E ayat (1) dan ayat (2) UUD 1945 mengatur agama dan kepercayaan secara terpisah.

Oleh karena itu, istilah agama dan kepercayaan memang dipahami sebagai dua hal berbeda yang disetarakan. MK menyatakan bahwa status penghayat kepercayaan dapat dicantumkam dalam kolom agama di KK dan e-KTP tanpa perlu merinci aliran kepercayaan yang dianutnya.Hak untuk menganut agama atau kepercayaan terhadap Tuhan Yang Maha Esa merupakan hak konstitusional warga negara, bukan pemberian negara. Oleh sebab itu, negara wajib melindungi dan menjamin pemenuhan hak warga negaranya untuk memeluk suatu kepercayaan di luar enam agama yang berkembang di Indonesia.

\section{Penutup \\ Simpulan}


Berdasarkan uraian tersebut tidak mempunyai kekuatan hukum maka dapat ditarik kesimpulan bahwa mengikat. Pemahaman tersebut Ahmadiyah seringkali menjadi target muncul karena Pasal 28E ayat (1) dan tindakan pelanggaran kebebasan ayat (2) UUD 1945 mengatur agama beragama dan berkeyakinan. Hal ini dan kepercayaan secara terpisah. dapat dilihat dari laporan tahunan Dengan demikian, istilah 'agama' dan Komnas HAM maupun Setara 'kepercayaan' memang dipahami Institute, ini terjadi karena sebagai dua hal berbeda yang pemberlakuan Undang-Undang disetarakan. MK menyatakan bahwa Pencegahan Penyalahgunaan dan / status penghayat kepercayaan dapat atau Penodaan Agama. dicantumkam dalam kolom agama di Sebagaimana diketahui, ada 187 aliran KK dan e-KTP tanpa perlu merinci kepercayaan tingkat pusat di Indonesia aliran kepercayaan yang dianutnya.

yang tercatat di Kementerian Pendidikan dan Kebudayaan.

\section{Saran}

Penyelesaian Putusan MK itu membuat Kementerian Dalam Negeri perlu mengubah UU Adminduk, mengakomodir 187 aliran kepercayaan di sistem kependudukan, dan mengubah format e-KTP menjadi agama/kepercayaan.

Penganut aliran kepercayaan memiliki kedudukan hukum yang sama dengan pemeluk enam agama yang diakui pemerintah, dalam memperoleh hak terkait administrasi kependudukan. MK memutuskan pasal 61 Ayat (2) dan pasal 64 ayat (5) UU Adminduk 1. Penganut dari kepercayaan yang belum di akui resmi oleh pemerintah boleh mengosongkan kolom agama dalam KTP elektronik atau e-KTP. Pemerintah Kabupaten/Kota berkewajiban dan bertanggung jawab menyelenggarakan urusan Administrasi kependudukan yang dilakukan oleh Bupati/ Walikota dengan kewenangan.

2. Terjadinya dinamika kasus Ahmadiyah dan penyelesaiannya terhadap agama maka pemerintah bertentangan dengan UUD 1945 dan 
sebagai lembaga tertinggi harus bersikap netral

\section{Daftar Pustaka}

Buku:

Andi Ayyub Saleh. 2006. Tamasya Perenungan Hukum dalam "Law in Book and Law in Action" Menuju Penemuan Hukum (Rechtsvinding), Jakarta: Yarsif Watampone,

Baidhawi, Zakiyuddin. 2005. Kredo Kebebasan Beragama. Jakarta: PSAP Muhammadiyah;

Erwin Muhammad. 2013. Pendidikan Kewarganegaraan Republik Indonesia. Bandung: Reflika Aditama,
Na'imah, Hayatun. "Perda Berbasis Syari'ah Dalam Tinjauan Hukum Tata Negara." Khazanah: Jurnal Studi Islam dan Humaniora 14, no. 1 (2016): 2740.

Sigit Ardianto. 2009. From Secularism into Modifed Pluralism : Comprehensive Application of John Rawls's Justice as Fairness Theory in Defining State and Religion Relationship, Cornel llaw Library

\section{Data Elektronik:}

https://tirto.id/kasus-kasusintoleransi-yang-menimpaahmadiyah-cp4V, https://news.detik.com/berita/369584 8/komnas-ham-ahmadiyah-korbandiskriminasi-karena-uu-pnps. Diakses tanggal 19 Desember 2017 